Interdyscyplinarne Konteksty Pedagogiki Specjalnej
NUMER 8/2015

\title{
Rola czasopisma „Szkoła Specjalna” w kształtowaniu społecznego wizerunku dziecka z niepełnosprawnością w Polsce w okresie międzywojennym (1924-1939)
}

\begin{abstract}
Aвstract: Apanel Danuta, The Role of "The Special School" Magazine in the Change of Situation of Children With Special Needs in Poland in the Interwar Period (1924-1939) [Funkcje czasopisma „Szkoła Specjalna” na rzecz zmiany sytuacji dziecka z niepełnosprawnością w Polsce w okresie w okresie międzywojennym (1924-1939)]. Interdyscyplinarne Konteksty Pedagogiki Specjalnej, nr 8, Poznań 2015. Pp. 43-57. Adam Mickiewicz University Press. ISBN 978-83-232-2902-5. ISSN 2300-391X.

This study shows the most important roles of the quarterly magazine "The Special School" and its contribution to the change of situation of children with special needs in Poland in the interwar period. The first part presents the complex conditions related to politics, legislation and specific economic, edu-cational and social circumstances that greatly influenced lives of the families having children with special needs in 2nd Republic of Poland. The second part reviews the functions the magazine fulfilled at that time: informative, opinion-shaping, educative, motivating for changes and inspiring to find new solutions in education for children with special needs.
\end{abstract}

KEY wORDs: child with special needs, "The Special School” magazine, interwar period, roles. 


\section{Wybrane uwarunkowania sytuacji społecznej dziecka z niepełnosprawnością w II RP w zarysie}

Najważniejszym celem opracowania jest ukazanie funkcji, jakie pełniło czasopismo „Szkoła Specjalna” w procesie zmian prowadzących do poprawy sytuacji społecznej dziecka z niepełnosprawnością w okresie dwudziestolecia międzywojennego. Podstawowym materiałem źródłowym wykorzystanym w opracowaniu są kolejne numery tego czasopisma wydawane w latach 1924-1939, zwłaszcza artykuły, które poruszały tę tematykę.

Sytuację społeczną dziecka z niepełnosprawnością w tym okresie kształtowały złożone uwarunkowania o charakterze politycznym, legislacyjnym, ekonomicznym, oświatowym i społecznym. Odzyskanie niepodległości zapoczątkowało zmiany i dało możliwość podejmowania przez rząd II RP suwerennych decyzji. Wśród pilnych problemów pojawiło się zagadnienie odbudowy ogólnodostępnego szkolnictwa, w tym mocno zaniedbanego obszaru placówek edukacyjnych dla dzieci z niepełnosprawnością. Świadczą o tym słowa zamieszczone na łamach pierwszego numeru czasopisma „Szkoła Specjalna":

[...] Państwo Polskie walcząc z trudnościami finansowemi wolno bardzo, ale stopniowo tworzy i rozwija szkoły, daje projekty i plany nowych organizacji. Słowem w całokształcie systematu szkolnego bierze pod uwagę i ten ważny ze wszech miar problem ${ }^{1}$.

Do najważniejszych dokumentów legislacyjnych, które wpływały na sytuację dziecka z niepełnosprawnością w okresie dwudziestolecia międzywojennego, należy Dekret o obowiązku szkolnym z dnia 7 lutego 1919 r., wydany przez Józefa Piłsudskiego, który stanowi:

[...] od obowiązku szkolnego mogą być uwolnione dzieci chore fizycznie (szczególnie z gruźlicą otwartą) lub umysłowo oraz dzieci niedorozwinięte,

${ }^{1}$ M. Grzegorzewska, M. Wawrzynowski, Zamiast programu, „Szkoła Specjalna” 1924, nr 1, s. 2. 
jeżeli ich ułomności wyłączają je od pobierania nauki w szkole powszechnej. Jeśli w danej miejscowości istnieje zakład kształcenia chorych, kalek, ciemnych, głuchoniemych i niedorozwiniętych, obowiązek szkolny rozciąga się na te dzieci².

Również dzieci, które mieszkały w odległości większej niż 3 km od szkoły, na mocy Dekretu były zwolnione od obowiązku szkolnego ${ }^{3}$.

Podstawowe prawa dziecka do ochrony i opieki zostały sformułowane w Konstytucji z 17 marca 1921 r., w art.: 102, 103, 118, 119, 120. „Ponad to Konstytucja gwarantowała prawo do bezpłatnej nauki w szkołach publicznych wszystkim dzieciom" ${ }^{4}$.

Kolejnym dokumentem prawnym, który regulował kwestię edukacji dziecka z niepełnosprawnością była ustawa o ustroju szkolnictwa z dnia 11 marca 1932 r. Art. 13 tej stwierdzał, że: „wychowanie i kształcenie dzieci anormalnych odbywa się w zakładach i szkołach powszechnych specjalnych względnie w oddziałach specjalnych". Jednocześnie w innym miejscu (art. 8) ustawa wyjaśniała, że „czas trwania obowiązku szkolnego dzieci anormalnych określi MWRiOP i że dzieci anormalne mogą być zwolnione z obowiązku szkolnego, jeśli nie ma zorganizowanej dla nich szkoły specjalnej na terenie ich zamieszkania i pobytu” ${ }^{5}$. Zatem „ustawa nie gwarantowała faktycznie realizacji obowiązku szkolnego dla dzieci niepełnosprawnych"6.

Głęboki kryzys ekonomiczny w latach 1929-1935 „w poważnym stopniu zaważył na losach oświaty i opieki nad dzieckiem. W latach 1929-1935 nastąpiło wyraźne obniżenie wskaźnika realizacji przez dzieci obowiązku szkolnego w stosunku do okresu poprzedniego. W roku szkolnym 1928/29 poza szkołą znajdowało się około 121 tys.

${ }^{2}$ Cyt. za: M. Balcerek, Szkolnictwo specjalne i pedagogika specjalna w pierwszej potowie XX wieku, [w:] Dzieje szkolnictwa i pedagogiki specjalnej, red. S. Mauersberg, Warszawa 1990, s. 207.

${ }^{3}$ Ibidem.

4 Ibidem, s. 208.

5 Ibidem, s. 211.

${ }^{6}$ Ibidem. 
dzieci, a w roku szkolnym 1935 (według obliczeń ZNP) pozostawało poza nauką szkolną około miliona dzieci" ${ }^{\prime 7}$.

Również ważne wydarzenia społeczne i oświatowe okresu II RP dotyczyły opieki nad dziećmi niepełnosprawnymi oraz systemu ich kształcenia. Jednym z nich był Ogólnopolski Zjazd Nauczycielski, który odbył się w dniach 14-19 kwietnia 1919 r. „Stosunkowo wiele uwagi zjazd poświęcił zagadnieniom opieki nad dzieckiem »chorym, kalekim i upośledzonym «" ${ }^{\prime \prime}$. Podczas Zjazdu referaty na ten temat wygłaszali m.in.: Stanisław Kopczyński, Tadeusz Jaroszyński i Władysław Jarecki ${ }^{9}$, którzy wskazywali:

[...] wśród ogółu dzieci szkolnych jest około 6\% dzieci fizycznie i umysłowo upośledzonych, które wymagają szczególnej opieki i specjalnych form kształcenia. Obowiązki w tej dziedzinie powinny ciążyć na państwie. Dla roztoczenia prawidłowej opieki nad dziećmi proponowano wprowadzenie ustawowego obowiązku szkolnego oraz szerokiej sieci zakładów specjalnych dla dzieci niewidomych, głuchych, upośledzonych umysłowo oraz dla mało zdolnych i opóźnionych w rozwoju umysłowym ${ }^{10}$.

Kolejnym znaczącym wydarzeniem było powołanie Państwowego Seminarium Pedagogiki Specjalnej w 1921 r., Państwowego Instytutu Pedagogiki Specjalnej w 1922 r. oraz Sekcji Szkolnictwa Specjalnego przy Związku Polskiego Nauczycielstwa Szkół Powszechnych w $1924 \mathrm{r}$.

Duże znaczenie w dyskusji społecznej nad sytuacją dziecka z niepełnosprawnością w II RP miały kolejno organizowane Zjazdy Nauczycieli Szkół Specjalnych oraz Ogólnopolski Kongres Dziecka. Pierwszy Zjazd odbył się odbył się w dniach 19-22 grudnia $1925 \mathrm{r}$. w Warszawie w salach Państwowego Instytutu Głuchoniemych i Ociemniałych.

\footnotetext{
7 Ibidem, s. 209.

8 Ibidem, s. 207.

9 Ibidem.

10 Ibidem, s. 208.
} 
Naczelnym zadaniem zjazdu było dążenie do nawiązania wzajemnej łączności wśród wszystkich pracowników szkolnictwa specjalnego, a więc zarówno wśród nauczycieli czynnych w tej dziedzinie, jak i osób pracujących na polu naukowem i społecznem, współdziałających w rozwoju problemu kształcenia anormalnych i organizowania opieki nad niemi. Program Zjazdu wychodził z założenia, że zadanie to ma znaczenie zasadnicze, uzależniające możliwość porozumienia się w sprawie rozwoju zagadnień organizacyjnych tego szkolnictwa oraz metod nauczania i wychowania dzieci anormalnych. To nawiązanie łączności, uzależniające zespolenie $\mathrm{w}$ pracy i wymianę myśli, jest nieodzownym warunkiem do postawienia sobie choćby najogólniejszych postulatów pracy na przyszłość ${ }^{11}$.

Drugi Zjazd Nauczycieli Szkół Specjalnych miał miejsce w 1934 r. Jego uczestnicy krytycznie ustosunkowali się do ustawy o ustroju szkolnym z 1932 r. Domagali się m.in.: przedłużenia obowiązku szkolnego dzieci niepełnosprawnych do 16. roku życia, unormowania obowiązku przygotowania zawodowego młodzieży niepełnosprawnej oraz ograniczenia liczby dzieci niepełnosprawnych w klasach do 20, a na okres trudności gospodarczych - do 24 uczniów $^{12}$.

Ogólnopolski Kongres Dziecka przebiegał w dniach od 2-4 października 1938 r. „Obrady kongresu toczyły się wokół dwóch zasadniczych problemów: stosunku społeczeństwa do dziecka i jego potrzeb społecznych oraz podstawowych praw dzieci i młodzieży"13. Przedstawiono wówczas wniosek o rozbudowę zakładów i szkół specjalnych dla dzieci z różnego rodzaju niepełnosprawnościami ${ }^{14}$.

Dużą wartość wartość dla sytuacji i wizerunku dziecka z niepełnosprawnością w II RP miała działalność naukowa i praktyczna wybitnych pedagogów: Marii Grzegorzewskiej, Józefy Joteyko, Jana Hellmana, Michała Wawrzynowskiego, Janusza Korczaka, Natalii Han-Ilgiewicz, Janiny Doroszewskiej i Marii Stefanowskiej.

11 Sprawozdanie z I Polskiego Zjazdu Nauczycieli Szkót Specjalnych, „Szkoła Specjalna" 1926, nr 2, s. 69.

${ }^{12}$ M. Balcerek, op. cit., s. 211.

13 Ibidem.

14 Ibidem, s. 212. 
Również działalność wydawnicza w ramach Biblioteki Pedagogiki Leczniczej przynosiła widoczne rezultaty. Szczególne znaczenie miała publikacja Jana Hellmana Szkoły i zakłady dla dzieci anormalnych jako kwestia społeczna oraz projekt sieci szkót specjalnych na terenach Rzeczypospolitej w zwiazku z materiałami statystycznymi (1921). Praca ta miała charakter programowy i po niewielkich uzupełnieniach stała się wytyczną działalności oświatowej i opiekuńczej w ówczesnej Polsce w dziedzinie opieki nad dzieckiem niepełnosprawnym. Na uwagę zasługują także publikacje Marii Grzegorzewskiej, Michała Wawrzynowskiego, Władysława Sterlinga i Gustawa Bychowskiego ${ }^{15}$.

\section{Czasopismo „Szkoła Specjalna” inicjatorem zmian w społecznym wizerunku dziecka z niepełnosprawnością w II RP}

Czasopismo „Szkoła Specjalna”16 odegrało „podstawową rolę w upowszechnianiu dorobku praktycznego i teoretycznego pedagogiki specjalnej w latach międzywojennych"17. Treści czasopisma zostały podzielone na stałe części: Artykuły, Z pracy nauczycielskiej, Sprawozdania i oceny, Polemika, Kronika krajowa, Kronika zagraniczna, Książki nadesłane, Streszczenia francuskie ${ }^{18}$.

15 Ibidem, s. 208.

16 „Szkoła Specjalna” - „kwartalnik poświęcony sprawom wychowania i nauczania anormalnych, organ sekcji szkolnictwa specjalnego przy Związku Polskiego Nauczycielstwa Szkół Powszechnych. Redaktor - dr Maria Grzegorzewska. Wydawca w imieniu Związku Polskich Nauczycieli Szkół Powszechnych i redaktor odpowiedzialny - Michał Wawrzynowski. Warszawa, redakcja: pl. Trzech Krzyży 4-6, Państwowy Instytut Pedagogiki Specjalnej; Tel. 13-06. Administracja: ul. Świętokrzyska Nr 30, Tel. 269-49; Konto PKO 9503". Informacja pochodzi z pierwszej strony, pierwszego numeru czasopisma z października-grudnia 1924 r. Począwszy od 1933 r., zmieniają się dane dotyczące redaktora odpowiedzialnego (Józef Czechowicz), wydawcy (Stanisław Machowski), adresu (od 1932 r. przy Al. Ujazdowskich 20, a od 1933 r. na Wybrzeżu Kościuszkowskim 33).

17 M. Balcerek, op. cit., s. 218.

${ }^{18}$ Informacja pochodzi ze s. 2 pierwszego numeru czasopisma. 
Czasopismo pełniło przede wszystkim funkcję informacyjną. $\mathrm{Na}$ jego łamach publikowano artykuły dotyczące środowiska osób niepełnosprawnych i ich rodzin oraz uświadamiano społeczeństwo w kwestiach kondycji zdrowotnej i społecznej tych osób, głównie dzieci. Informowano także o funkcjonowaniu ośrodków opiekuńczych i zakładów specjalnych dla dzieci niepełnosprawnych. $\mathrm{W}$ pierwszym numerze czasopisma redaktorzy napisali:

Poza artykułami o treści naukowej, informacyjnej i sprawozdawczej „Szkoła Specjalna" będzie umieszczać sprawozdania ze zwiedzania zakładów specjalnych, z odpowiednich kongresów i zjazdów, sprawozdania z prac polskich i zagranicznych $\mathrm{w}$ dziedzinie psychopatologii, pedagogiki leczniczej i opieki społecznej oraz sprawozdania z krajowych i zagranicznych czasopism pedagogiki specjalnej. Oprócz działu sprawozdawczego „Szkoła Specjalna" zamierza prowadzić dla informacji czytelników kronikę ważniejszych wypadków w kraju i za granicą w dziale opieki nad anormalnymi ${ }^{19}$.

Informacje i objaśnienia o charakterze edukacyjnym, ukazujące się na łamach czasopisma, pozwalały czytelnikom poznać zasadnicze problemy związane z dysfunkcjami i ich genezą. W ówczesnych warunkach, w sytuacji małego dostępu do źródeł wiedzy, ta droga była bardzo ważna. Edukacyjną tematykę podejmowali w swych opracowaniach głównie lekarze. Na przykład Benedykt Dylewski $\mathrm{w}$ artykule Wady mowy i ich leczenie na terenie szkoty pisał:

Choroby mowy (bełkotanie, jąkanie, seplenienie, mowa nosowa) są bardzo rozpowszechnione; szczególnie często występują one u dzieci. Wiele z tych cierpień należy do udzielających się; dziecko może nabyć wadę od rodziców, nianiek, kolegów. Dlatego też ważnym jest, aby dzieci, zwłaszcza w okresie rozwoju mowy, miały wokół siebie tylko dobre jej wzory. Bardzo szkodliwy, niestety rozpowszechniony jest zwyczaj naśladowania przez starszych w pieszczotliwej formie złej wymowy dziecka. Naśladownictwo obok dziedziczności i złego przyzwyczajenia odgrywa ważną rolę w powstawaniu wad mowy ${ }^{20}$.

19 M. Grzegorzewska, M. Wawrzynowski, op. cit., s. 3.

${ }^{20}$ B. Dylewski, Wady mowy $i$ ich leczenie na terenie szkoły, "Szkoła Specjalna” 1930/1931, t. VII, s. 52. 
Władysław Sterling w opracowaniu Mongołowatość przedstawia problematykę życia biopsychicznego, społecznego i edukacyjnego osób z trisomią 21. W ówczesnej Polsce wiedza na ten temat miała skromny wymiar, a prawdziwe problemy tych osób i ich rodzin znali głównie lekarze.

Anomalia po raz pierwszy opisana została przez Langdona Downa w 1866 roku. Jest wrodzoną postacią zwyrodnienia cielesnego i psychicznego, postacią, która określana bywa również jako idiotyzm mongołowaty, a zawdzięcza swą nazwę podobieństwu do rasy mongolskiej²1.

Czasopismo „Szkoła Specjalna” było także głosem mobilizującym społeczeństwo do działań na rzecz poprawy sytuacji bytowej osób niepełnosprawnych i ich rodzin. Świadczą o tym liczne publikacje, m.in.: Anny Janowskiej, Janusza Korczaka i Antoniego Komorowskiego. W pierwszym numerze czasopisma „Szkoła Specjalna” z 1924 r. czytamy:

Społeczeństwo jednakże dotychczas prawie że udziału w tej akcji nie bierze, w dalszym ciągu zapatrując się na tę sprawę z punktu widzenia dobroczynności, może trochę humanitaryzmu... i to wszystko... Więc znowu trochę litości, miłosierdzia - tanecznych zabaw, rautów i koncertów kilka osób pełnych poświęcenia - ofiarnych i nic więcej. Żadnej syntezy, żadnego zrozumienia i właściwego ujęcia, żadnej zmiany w pobudkach działania! I dalej tą drogą utarło się dowodzenie, że najpierw trzeba zaspokoić w zupełności prawa do nauki i wychowania dziecka normalnego, potem może, kiedyś, jak szkoły wszystkie dla normalnych będą już zaopatrzone - i ta kwestia wypłynie. I społeczeństwo nie widzi, bo zamyka oczy, konsekwencji, jakie to pociąga za sobą. Nie wie, bo wiedzieć nie chce, co stanie się z dzieckiem usuniętem ze szkoły normalnej, które wychowa ulica, głód, nędza, poniewierka i zły doradca - sprytniejszy kolega ${ }^{22}$.

Na łamach czasopisma z lat 1924-1939 można znaleźć przejmujące w swej wymowie fotografie, ryciny oraz opisy warunków życia

21 W. Sterling, Mongołowatość, „Szkoła Specjalna” 1935/1936, nr 2, s. 65.

22 M. Grzegorzewska, M. Wawrzynowski, op. cit., s. 3. 
warszawskich rodzin posiadających dzieci niepełnosprawne. Rodziny te mieszkały głównie na przedmieściach, w ruderach, piwnicach i suterenach, w pomieszczeniach zagrzybionych, często bez drzwi lub okien. Tymczasowość i niski standard warunków mieszkaniowych powodowały zagrożenie zdrowia i życia dzieci. Dodatkowo stan ten pogarszał brak opieki rodzicielskiej, a także choroby i uzależnienia. Trudna codzienność sprawiała, że dzieci poszukiwały dla siebie miejsca na ulicy. Artykuł Anny Janowskiej Warunki życia rodzin dzieci upośledzonych umysłowo w Warszawie ${ }^{23}$ dobrze obrazuje tę sytuację:

Prócz tych dzieci pociąganych przed Sąd dla nieletnich, zamykanych $\mathrm{w}$ areszcie za żebranie, bitych przez policjantów - są też w Warszawie takie dzieci, dla których miejsca wprost nie ma na świecie. Są to właśnie mali psychopaci z równoczesnym upośledzeniem umysłowym. Normalna szkoła czym prędzej się ich wyzbywa, szkoła specjalna dzisiejsza je usuwa, dom wypędza je na ulicę, która jedna przygarnia te istoty odepchnięte przez wszystkich, a podatne na wszelkie występki ${ }^{24}$.

Kolejną funkcją omawianego czasopisma było kształtowanie postawy nauczycieli wobec problemów społecznych i edukacyjnych dziecka z niepełnosprawnością. Twórcy czasopisma, redaktorzy i autorzy publikacji mobilizowali środowisko nauczycielskie, kształtowali w trudzie ich postawę, wzywali do obrony praw tych dzieci.

Stosunek świata nauczycielskiego do tego zagadnienia długo bardzo był raczej bierny zupełnie. Jednakże jednostki, które szły do ciężkiej, ale i ciekawej pracy przy tym warsztacie szkolnictwa, rozumiały ważne znaczenie społeczne i pedagogiczne tego problematu i szły do pracy z przekonaniem, że idą służyć zapoznanej, ale doniosłej sprawie, w której rozwoju współdziałać należy, wpływając na jej należyte zrozumienie, ujęcie oraz na wyrobienie czynnego do niej stosunku kolegów i społeczeństwa. Ideowa i wytężona praca kolegów w szkołach specjalnych, nowopowstające placówki na tem polu, wreszcie stale posuwająca się naprzód realizacja obowiązku szkolnego

${ }^{23}$ A. Janowska, Warunki życia rodzin dzieci upośledzonych umystowo w Warszawie, „Szkoła Specjalna” 1936/1937, nr 1, s. 11.

${ }^{24}$ Ibidem, s. 22. 
zaczęły stopniowo i coraz żywiej zwracać uwagę całego świata nauczycielskiego na zagadnienie opieki wychowawczej nad dziećmi anormalnemi ${ }^{25}$.

Wymiana myśli i doświadczeń w zakresie kształcenia dzieci niepełnosprawnych i doskonalenia metod pracy z nimi to kolejna funkcja kwartalnika „Szkoła Specjalna”. Zagadnieniem, któremu poświęcano wiele uwagi, było przygotowanie uczniów niepełnosprawnych do pracy zawodowej. Wskazywano na potrzebę takiego kszt1cenia, by w zależności od rodzaju dysfunkcji i stopnia jej nasilenia uczniowie ci mogli pracować i zarabiać na swoje utrzymanie.

Maria Strasburger w artykule Wybór zawodu dla młodzieży niedorozwiniętej pisze:

Dla upośledzonych wybierać trzeba zawody nie wymagające poczucia odpowiedzialności, skupienia uwagi, szybkiej orientacji ani zmysłu kombinacyjnego, zawody, w których mniejsze jest niebezpieczeństwo nieszczęśliwych wypadków, wykonywane pod ciągłym dozorem, nie wystawiające na pokusy ulicy i niebezpieczeństwo złego towarzystwa oraz nie oddziaływujące szkodliwie na zdrowie. Bardzo stosowne dla nienormalnych są zawody automatyczne, jednostajne. $\mathrm{W}$ zawodach tych niedorozwinięci dochodzą niejednokrotnie do większej wprawy i doskonałości niż robotnicy myślący i inteligentni ${ }^{26}$.

Władysław Jarecki w artykule Braki szkolnictwa specjalnego w Polsce porusza zagadnienie opieki i kształcenia osób niewidomych i głuchych. Wskazuje na problemy tych osób związane z ich codziennym życiem i potrzebami. Uświadamia, że niewidomi i głusi mogą spełniać się w rolach społecznych i zawodowych przy pomocy zdrowej części społeczeństwa.

Ociemniali należą do kategorii ludzi, którzy mogą pracować na swoje utrzymanie, lecz nie są w stanie obejść się bez opieki ze strony społeczeństwa, co wynika z samej istoty ich kalectwa. Po ukończeniu więc szkoły ociemniały

${ }^{25}$ M. Grzegorzewska, M. Wawrzynowski, op. cit., s. 2.

${ }^{26}$ M. Strasburger, Wybór zawodu dla młodzieży niedorozwiniętej, „Szkoła Specjalna" 1925, nr 3, s. 188-196. 
nie jest w stanie poszukać sobie lokalu i zarobkować, on musi mieć ten lokal i warsztat przygotowany, o ile go nie ma, życie stanie się dla niego nie do zniesienia: po wielu poniżeniach i kłopotach może być umieszczony w schronisku dla nieuleczalnych, gdzie będzie wegetował wśród starców i kalek ${ }^{27}$.

Janusz Korczak zajmuje uwagę czytelników problematyką małych dzieci. Życie w środowisku dysfunkcjonalnym zmusza je do popełniania czynów zabronionych i społecznie nagannych. Uzasadnia więc konieczność powołania placówek ponownej socjalizacji dla małych dzieci na odrębnych zasadach niż pozostałe dla starszej młodzieży i dorosłych. Problem ten porusza w artykule Dzieci występne w wieku przedszkolnym:

Byłoby śmieszne domagać się zakładów karnych czy poprawczych dla pięcioletnich występnych. Ale i dla młodzieży występnej żądamy zakładów leczniczych. W większym stopniu są one potrzebne dla najmłodszych. Bo społeczeństwo to jest zupełnie nieradne, bo obronić się samo nie może, bo opieka nie może, nie umie, nie wie, jak niemi kierować i stosuje jedynie metodę klapsa i zamknięcia w ciemnej komórce ${ }^{28}$.

Zagadnieniem, które pozostawało pilną, ale trudną do rozwiązania sprawą w okresie II RP był system opieki nad dziećmi niedostosowanymi społecznie, szczególnie tymi, które popełniły czyny karalne. Na stronach czasopisma „Szkoła Specjalna” znajduje się wiele publikacji na ten temat. Na przykład Antoni Komorowski (sędzia dla nieletnich miasta stołecznego Warszawy) ${ }^{29}$ w artykule Sądy dla nieletnich w Polsce pisał:

Sprawa należytej i prawidłowej opieki nad opuszczonemi, zaniedbanemi i krzywdzonemi dziećmi, które już popełniły przestępstwo lub są na drodze

${ }^{27}$ W. Jarecki, Braki szkolnictwa specjalnego w Polsce, „Szkoła Specjalna” 1925, nr 3, s. $211-218$.

${ }^{28}$ J. Korczak, Dzieci występne w wieku przedszkolnym, „Szkoła Specjalna” 1925, nr 3, s. 243.

${ }^{29}$ A. Komorowski, Sądy dla nieletnich w Polsce, „Szkoła Specjalna” 1925, nr 3, S. 253. 
do niego, jest nader żywotną i nie da się rozwiązać jedynie staraniem sił społecznych w postaci różnego rodzaju towarzystw, lig, patronatów i kół opieki oraz pomocy tym przyszłym obywatelom kraju, którym los w zaraniu ich życia nie dał należytej opieki. $W$ tym względzie państwo winno w szerokim zakresie dopomóc siłom społecznym lub całkowicie ująć w swe ręce opiekę nad nieletnimi, gdyż w przeciwnym razie nie uleczy chorych tkanek, a spowoduje powolny rozkład całego organizmu. [...] Dziecko, które popełniło przestępstwo, wymaga nie kary, lecz racjonalnego wychowania, opieki i pomocy ${ }^{30}$.

Zofia Rozenblum na łamach pisma analizuje tę problematykę w kontekście dzieci niepełnosprawnych. W artykule Dzieci specjalnej troski $i^{31}$ napisała:

Brak izby zatrzymań nie pozwala poddać podsądnych dłuższej obserwacji ani wyrwać ich z dotychczasowego środowiska, co najczęściej jest wprost nieodzownym warunkiem dokładnego zorientowania się, z jakim typem dziecka ma się do czynienia. $W$ braku odpowiednich zakładów opiekunczo-wychowawczych sędzia jest niejednokrotnie zmuszony zastosować natychmiastowe osadzenie $\mathrm{w}$ areszcie, o ile podsądny jest zupełnie bezdomnym, względnie nałogowym włóczęgą" ${ }^{32}$.

Z przytoczonego fragmentu wynika, że w systemie opiekuńczym okresu II RP brakowało specjalnych zakładów dla dzieci z dysfunkcjami, które popełniały czyny karalne. Powierzchowna diagnoza stawała się najczęściej początkiem niewłaściwych decyzji związanych $\mathrm{z}$ resocjalizacją tej grupy nieletnich.

Czasopismo „Szkoła Specjalna” pełniło również funkcję kształcącą w odniesieniu do nauczycieli i całego społeczeństwa. Wskazuje na to chociażby fragment artykułu Zamiast programu Marii Grzegorzewskiej i Michała Wawrzynowskiego ${ }^{33}$ :

\section{Ibidem.} S. $19-43$.

${ }^{31}$ Z. Rozenblum, Dzieci specjalnej troski, „Szkoła Specjalna” 1928/1929, nr 1-2,

${ }^{32}$ Z. Rozenblum, op. cit., s. 19.

${ }_{33}$ M. Grzegorzewska, M. Wawrzynowski, op. cit., s. 2. 
Służąc zarówno rozwojowi metod nauczania i wychowania anormalnych, jak i założeniom samokształceniowym nauczycieli szkół specjalnych, „,Szkoła Specjalna" winna być jednym z podstawowych terenów wymiany myśli, czerpania wiadomości w dziedzinie naukowej, organizacyjnej i metodologicznej tego szkolnictwa oraz zbliżenia intelektualnego rozsianych po całym kraju Kolegów i Koleżanek. Wszyscyśmy pracujący na tej niwie przynieść tu winni ku pożytkowi ogólnemu nasze wiadomości, doświadczenia i obserwacje poparte wynikami pracy. Nie usuwać się z niechęcią, nie patrzeć biernie na tę pracę, nie krytykować na uboczu, a więc nieprodukcyjnie, lecz z myślą życzliwą i z wiarą w pomyślny rozwój wziąć w niej żywy udział. Współdziałać $\mathrm{w}$ opracowywaniu zagadnień metodologicznych i organizacyjnych, nadsyłać informacje, zapytania, krytyczne uwagi co do kierunku, charakteru i rozwoju pisma, tak aby każdy z nas czuł się współtwórcą i współpracownikiem ${ }^{34}$.

Funkcję kształcącą odzwierciedla również opracowanie Sergiusza Hessena Pedagogika specjalna i pedagogika ogólna ${ }^{35}$. Autor pisze w nim:

[...] wychowanie dzieci anormalnych odróżnia się od wychowania dzieci normalnych nie zasadniczo, lecz charakterem swej negatywnej strony, czyli swej techniki. [...] W pedagogice specjalnej największy akcent kładzie się na kompensację braków tkwiących w organizmie wychowanka. W wychowaniu dzieci normalnych akcent ten przesuwa się na usunięcie przeszkód przez jak najbardziej higieniczną i ekonomiczną organizację pracy wychowawczej oraz na kompensację braków środowiska społecznego ${ }^{36}$.

Czasopismo „Szkoła Specjalna” przyczyniało się zatem do szerokiej pedagogizacji społeczeństwa na temat osób niepełnosprawnych, do podnoszenia poziomu wiedzy i kształtowania świadomości społecznej w tym zakresie. Pedagodzy, psycholodzy, lekarze i działacze społeczni skupieni wokół Marii Grzegorzewskiej, „przenosząc i adaptując na grunt polski doświadczenia krajów europejskich, opraco-

34 Ibidem, s. 3.

35 S. Hessen, Pedagogika specjalna i pedagogika ogólna, „Szkoła Specjalna” 19371939, nr 1-5.

36 Ibidem, s. 12. 
wali podstawy organizacji szkolnictwa specjalnego w Polsce, jednocześnie próbując budować własną, swoiście polską, teorię kształcenia i wychowania upośledzonych" ${ }^{37}$.

\section{Podsumowanie}

Analiza treści artykułów zamieszczonych na łamach kwartalnika „Szkoła Specjalna” z okresu międzywojennego (1924-1939) pozwala na sformułowanie następujących wniosków na temat sytuacji społecznej dziecka z niepełnosprawnością.

1. Czasopismo to odegrało przede wszystkim funkcję informacyjną oraz kształtującą postawy społeczeństwa wobec problemów osób niepełnosprawnych.

2. Informacje docierały do środowisk społecznych za pośrednictwem nauczycieli, pedagogów specjalnych pracujących w szkołach i zakładach specjalnych (możliwa była prenumerata czasopisma).

3. Ważnym czynnikiem warunkującym rozpowszechnianie wiedzy na temat dziecka z niepełnosprawnością był nakład wydawniczy kwartalnika. Niestety, w analizowanym okresie $\mathrm{w}$ stopce redakcyjnej czasopisma nie ma informacji na temat nakładu. Natomiast pojawiały się zapisy ${ }^{38}$, że członkowie ZNP otrzymywali bezpłatnie czasopismo "Szkoła Specjalna" jako dodatek do "Głosu Nauczycielskiego".

4. Istotny był wysoki poziom aktywności pedagogów teoretyków i praktyków w kwestii podejmowania na łamach prasy, $\mathrm{w}$ środowiskach pracy i $\mathrm{w}$ środowiskach społecznych walki o prawa dziecka niepełnosprawnego oraz inicjowania działań społecznych na rzecz poprawy warunków życia ich rodzin.

5. Rzeczywista sytuacja społeczna dziecka z niepełnosprawnością w II RP odbiegała od obrazu postulowanego i kreowane-

${ }^{37}$ M. Balcerek, op. cit., s. 219.

38 „Szkoła Specjalna” 1933/1934, nr 2 i 3. 
go na łamach czasopisma „Szkoła Specjalna”. Świadczą o tym chociażby wspomniane artykuły Antoniego Komorowskiego czy Zofii Rozenblum.

Wykluczenie społeczne towarzyszyło dzieciom niepełnosprawnym wówczas, następnie przez ponury okres Polski Ludowej, a w dzisiejszych czasach, mimo deklarowanych i realnych działań inkluzyjnych, wciąż jest obserwowanym zjawiskiem.

\section{Bibliografia}

BALCEREK M., Szkolnictwo specjalne i pedagogika specjalna w pierwszej połowie XX wieku, [w:] Dzieje szkolnictwa i pedagogiki specjalnej, red. S. Mauersberg, Warszawa 1990.

DyLewski B., Wady mowy i ich leczenie na terenie szkoły, "Szkoła Specjalna” 1930/1931, t. VII.

Grzegorzewska M., Wawrzynowski M., Zamiast programu, „Szkoła Specjalna” 1924, nr 1.

Hessen S., Pedagogika specjalna i pedagogika ogólna, „Szkoła Specjalna” 1937-1939, nr 1-5. JANOWSKA A., Warunki życia rodzin dzieci upośledzonych umysłowo w Warszawie, „Szkoła Specjalna" 1936/1937, nr 1.

JARECKI W., Braki szkolnictwa specjalnego w Polsce, „Szkoła Specjalna” 1925, nr 3.

KомоRоwsкi A., Sądy dla nieletnich w Polsce, „Szkoła Specjalna” 1925, nr 3.

KorCZAK J., Dzieci występne w wieku przedszkolnym, „Szkoła Specjalna” 1925, nr 3.

Rozenblum Z., Dzieci specjalnej troski, „Szkoła Specjalna” 1928/1929, nr 1-2.

Sprawozdanie z I Polskiego Zjazdu Nauczycieli Szkól Specjalnych, "Szkoła Specjalna” 1926, nr 2.

STERLING W., Mongołowatość, „Szkoła Specjalna” 1935/1936, nr 2.

Strasburger M., Wybór zawodu dla młodzieży niedorozwiniętej, „Szkoła Specjalna” 1925, nr 3. 